\title{
CORRIGENDUM
}

\section{Revolutions in the head: Darwin, Malthus and Robert M. Young - CORRIGENDUM}

James A. Secord

https://doi.org/10.1017/S0007087420000631, Published online by Cambridge University Press, 11 March 2021

On pages 51 and 59 of the above article Robert M. Young is referred to as a "practicing psychiatrist'. This is incorrect and the correct description is 'psychoanalytic psychotherapist'.

The author apologises for this error.

\section{Reference}

Secord, J. (2021). Revolutions in the head: Darwin, Malthus and Robert M. Young. The British Journal for the History of Science, 54(1), 41-59. doi:10.1017/S0007087420000631

Cite this article: Secord JA (2021). Revolutions in the head: Darwin, Malthus and Robert M. Young CORRIGENDUM. The British Journal for the History of Science 54, 255. https://doi.org/10.1017/S0007087421000273 